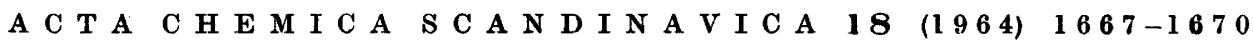

\title{
Unexpected Fraction from Collagen by Degradation in Alkaline Conditions
}

\author{
J. PIKK A R A I N EN and E. KULONEN
}

\author{
Department of Medical Chemistry, University of Turku, Turku 3, Finland
}

\begin{abstract}
When insoluble collagen was gelatinized in alkaline conditions at $+90^{\circ} \mathrm{C}$ or higher, there appeared in carboxymethyl cellulose column fractionation of the gelatins an unexpected peak, which contained more acid amino acids and less basic amino acids than the bulk.
\end{abstract}

Tn our previous work ${ }^{1}$ we encountered in the carboxymethyl (CM-) cellulose $\mathbf{L}_{\text {column fractionation of gelatins a "three-peak-pattern", which was caused }}$ by an accidental infection of the samples. We tried without success to reproduce the finding. In the systematic study on the effect of various degradations, the pattern appeared again, when the conditions in the gelatinization had been alkaline and the temperature not too low.

\section{EXPERIMENTAL}

Samples. The present work was performed with the insoluble collagen of calf skin. The hair, epidermis and subcutaneous layer were removed from the fresh skins, which were cut into small pieces and thoroughly minced with a Bühler homogenizer. The material was then extracted three times overnight in a cold room with two volumes (per weight of fresh tissue) of $0.45 \mathrm{M}$ sodium chloride and subsequently nine times with the same volumes of $0.15 \mathrm{M}$ pH 3.7 sodium citrate buffer. The residue was regarded as insoluble collagen.

Degradation. The insoluble washed collagen was suspended in the tenfold volume (per weight of swollen material) of either $0.01 \mathrm{~N}$ hydrochloric acid, $0.01 \mathrm{M} \mathrm{pH} 4.8$ acetate buffer, $0.01 \mathrm{M}$ pH 10.5 sodium carbonate buffer or $0.01 \mathrm{~N}$ sodium hydroxide. Gelatinizations were carried out at the following temperatures: $+40^{\circ} \mathrm{C},+65^{\circ} \mathrm{C},+90^{\circ} \mathrm{C}$ and $120^{\circ} \mathrm{C}$, and the duration was extended from $15 \mathrm{~min}$ up to $120 \mathrm{~min}$. The insoluble residues were removed by centrifugation.

Fractionation. The procedure in the CM-cellulose fractionation has been described in detail elsewhere. ${ }^{2,3}$ The sample contained about $50-150 \mathrm{mg}$ of protein and the column was operated at $\mathrm{pH} 4.80$. Samples were dialyzed against $\mathrm{pH} 4.700 .01 \mathrm{M}$ sodium acetate buffer before the application into the column. During this procedure those gelatins which had been obtained in alkaline conditions precipitated, but the precipitate dissolved by

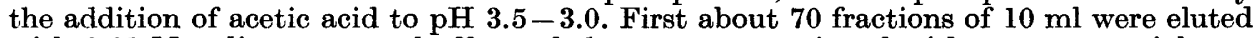
with $0.01 \mathrm{M}$ sodium acetate buffer and the run was continued with an exponential gradient of increasing concentrations (up to $0.86 \%$ ) of sodium chloride in the same buffer.

Acta Chem. Scand. 18 (1964) No. 7 
Analyses. The protein content of the fractions was determined according to Lowry et al. ${ }^{4}$ Gelatin samples were hydrolyzed in $5.7 \mathrm{~N}$ hydrochloric acid for $24 \mathrm{~h}$ at $+103^{\circ} \mathrm{C}$ in nitrogen atmosphere, and amino acid analyses were performed according to Spackman et al..$^{5}$ For the calibration of the procedure, a gelatin sample from the British Glue and Gelatine Research Association (courtesy of Dr. A. A. Leach) was analyzed simultaneously and the results agreed well with those published by Eastoe ${ }^{6}$ on the same sample (No. 149).

\section{RESULTS}

Fig. 1 shows examples of fractionation patterns, where the shaded areas (II) indicate the unexpected peak. This peak was not observed when the gelatinization had been performed at $\mathrm{pH} 4.8$ or in $0.01 \mathrm{~N}$ hydrochloric acid. At $\mathrm{pH} 10.5$ or in $0.01 \mathrm{~N} \mathrm{NaOH}$ the peak fraction II was formed only at $+90^{\circ} \mathrm{C}$ or $+120^{\circ} \mathrm{C}$. The increase of the alkalinity from $\mathrm{pH} 10.5$ to $0.01 \mathrm{~N} \mathrm{NaOH}$ did not make much difference. A similar peak was obtained also from neutral salt-soluble collagen of the guinea pig skin.

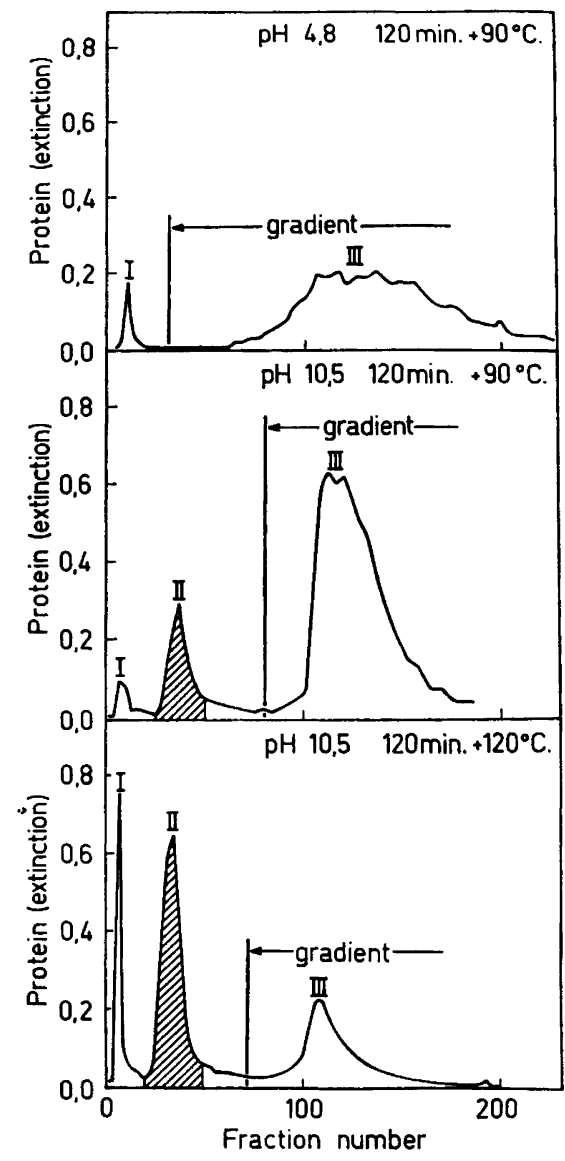

Fig. 1. Column chromatographic pattern of insoluble calf skin collagen gelatinized under indicated conditions. The conditions of carboxymethylcellulose column chromatography have been described in detail elsewhere. ${ }^{2,3}$ The shaded area (peak II) is the unexpected fraction. 
Table 1. Amino acid composition of fractions from gelatinized collagen. The samples and the designations of the fractions are shown in Fig. 1 and the results calculated as moles per 1000 moles, corrected for destruction during the hydrolysis.

\begin{tabular}{|c|c|c|c|c|c|c|}
\hline \multirow{2}{*}{ Amino acid } & \multicolumn{3}{|c|}{$\begin{array}{l}\text { Gelatinized at }+90^{\circ} \mathrm{C} \\
\text { for } 120 \mathrm{~min}\end{array}$} & \multicolumn{3}{|c|}{$\begin{array}{l}\text { Gelatinized at }+120^{\circ} \mathrm{C} \\
\text { for } 120 \mathrm{~min}\end{array}$} \\
\hline & $\mathbf{I}^{*}$ & II & III & I & II & III \\
\hline 3-Hydroxyproline $\ldots \ldots$. & $\ldots$ & - & trace & 4 & trace & - \\
\hline 4-Hydroxyproline $\ldots \ldots$ & . & 107 & 94 & $\mathbf{9 3}$ & 87 & 100 \\
\hline 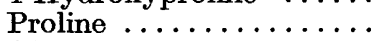 & $\ldots$ & 120 & 111 & 137 & 117 & 132 \\
\hline Glycine $\ldots \ldots \ldots \ldots \ldots$ & . & 357 & 348 & 336 & 342 & 329 \\
\hline Aspartic acid $\ldots \ldots \ldots$ & . & 57 & 48 & 55 & 57 & 36 \\
\hline Glutamic acid $\ldots \ldots \ldots \ldots$ & . & 84 & 83 & 84 & 94 & 85 \\
\hline Threonine $\ldots \ldots \ldots \ldots$ & $\ldots$ & 15 & 14 & 12 & 11 & 10 \\
\hline Serine $\ldots \ldots \ldots \ldots \ldots$ & . & 40 & 35 & 32 & 24 & 21 \\
\hline Alanine $\quad \ldots \ldots \ldots \ldots$ & . & 103 & 107 & 106 & 113 & 98 \\
\hline 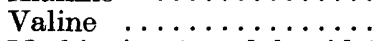 & . & 17 & 19 & 22 & 21 & 22 \\
\hline Methionine (+ sulphoxide) & . & 2 & 6 & 8 & 6 & 6 \\
\hline Isoleucine ( + alloform $).$ & . & $1 \overline{5}$ & 12 & 12 & 12 & 11 \\
\hline Leucine $\ldots \ldots \ldots \ldots$ & . & 22 & 22 & 27 & 27 & 25 \\
\hline Tyrosine $\ldots \ldots \ldots \ldots$ & . & 6 & 3 & 7 & 4 & trace \\
\hline Phenylalanine ........ & . & 14 & 13 & 12 & 10 & 10 \\
\hline Hydroxylysine & & & & & & \\
\hline$(+$ alloform $) \ldots \ldots \ldots$ & $\ldots$ & 1 & 7 & $\mathbf{3}$ & $\mathbf{3}$ & 10 \\
\hline Ornithine $\ldots \ldots \ldots \ldots$ & . & trace & 2 & 5 & 7 & 8 \\
\hline Lysine $\ldots \ldots \ldots \ldots \ldots$ & . & 18 & $2 \overline{6}$ & 19 & 29 & 35 \\
\hline Histidine $\ldots \ldots \ldots \ldots \ldots$ & . & - & 7 & 2 & 3 & 4 \\
\hline Arginine $\ldots \ldots \ldots \ldots \ldots$ & . & 22 & 43 & 24 & $\mathbf{3 3}$ & 58 \\
\hline Ammonia . . . . . . . . . & . & 48 & 38 & 65 & 34 & 61 \\
\hline Acid amino acids, total . . & . & 141 & 131 & 139 & 151 & 121 \\
\hline Basic amino acids, total. . & . & 41 & 85 & 53 & 75 & 115 \\
\hline
\end{tabular}

* Amounts too small to be analyzed reliably.

The amino acid composition of the fractions is shown in Table 1. Cystine and cysteic acid were present only as traces. The content of the acid amino acids (glutamic and aspartic acids) was higher and the content of the basic amino acids (hydroxylysine, ornithine, lysine, histidine and arginine) was lower in peak II than in the bulk peak III. It is remarkable that ornithine is not increased at the expense of arginine.

According to electrophoretic analyses the peak II is heterogeneous as also the bulk peak III. No distinct bands were obtained either in starch gel or in cellulose acetate sheets. The molecular weight of the material in the peak II is from 10000 to 50000 and even more as judged from the behaviour in various Sephadex-columns (G-25, G-50 and G-75).

\section{DISCUSSION}

The amino acid analyses are not in agreement with a suggestion that the appearance of the unexpected fraction would depend on the formation of ornithine from arginine ${ }^{7}$ or on the deamination of glutamine and asparagine during 
the treatment in alkaline conditions. ${ }^{8}$ In that case the frequency of the acid amino acids would be the same in peaks II and III, but an abundance of ornithine in peak II would be observed. An overlapping of the fractions II and III also would be expected.

Another explanation for peak II would involve the liberation of the acid segments of the peptide chains in these conditions and their accumulation in peak II. Grassmann et al. ${ }^{9}$ studied the tryptic hydrolyzates of purified soluble collagens by electrophoretic and column chromatographic (ion-exchange) methods and analyzed 51 individual peptides. Among these peptides there were several with acid total charge. Thus peak II may include large peptides containing these acidic portions from the polar regions of the tropocollagen molecule.

Acknowledgements. This work forms a part of a program supported by U.S. Department of Agriculture, through its Foreign Research and Technical Programs Division. Sigrid Jusélius Foundation has generously financed the equipment for amino acid analysis. We thank Dr. A. A. Leach, British Glue and Gelatine Research Association, for the sample of the gelatine reference.

\section{REFERENCES}

1. Kulonen, E., Virtanen, U. K. and Salmenperä, A. Acta Chem. Scand. 16 (1962) 1579.

2. Kulonen, E., Pikkarainen, J., Näntö, V. and Majaniemi, T. Proteinanalytisches Symposion Göttingen 1963.

3. Pikkarainen, J. and Kulonen, E. Suomen Kemistilehti B 37 (1964) 31.

4. Lowry, O. H., Rosebrough, N. J., Farr, A. L. and Randall, R. J. J. Biol. Chem. 193 (1951) 265.

5. Spackman, D. H., Stein, W. H. and Moore, S. Anal. Chem. 30 (1958) 1190.

6. Eastoe, J. E. Biochem. J. 79 (1961) 652.

7. Hamilton, P. B. and Anderson, R. A. J. Biol. Chem. 211 (1954) 95.

8. Kühn, K., Zimmer, E., Waykole, P. and Fietzek, P. Z. physiol. Chem. 333 (1963) 209.

9. Grassmann, W., Hannig, K. and Schleyer, M. Z. physiol. Chem. 322 (1960) 71.

Received May 14, 1964. 